\title{
"We'll fight for nature-light, truth-light and sunlight, against a world in swaddling clothes." Reconsidering the Aesthetic Dress Movement and Dress Reform in Nineteenth Century America
}

Jennifer Curtis, Queen's University

108

When Amelia Bloomer publicly donned pants in 1848 it marked the beginning of a well documented fight for female dress reform in America. Bloomer's subsequent abandonment of the reform costume several years later led both her contemporaries and modern day scholars to view the movement as a failure. Yet beneath the highly publicized "Bloomer Movement" lay a complex web of individuals, communities, and organizations who sought to challenge and reform female dress. In this paper I examine the notion of equality in female and male fashion in nineteenth century America, and challenge the Bloomerian notion that equated the appropriation of masculine attire with female empowerment. Through an examination of the late nineteenth century aesthetic dress movement I will indicate that though a celebration of "feminine" clothing the aesthetes made a lasting contribution to dress reform and female empowerment.

The subject of 'dress reform' has of late attracted a good deal of notice. Some ideas that have been advanced respecting it in certain quarters are rather more absurd than the fashions themselves. There is scarcely anything

Past Imperfect

13 (2007) | @ | ISSN 1192-1315 
that needs to be reformed at all in which the remedy is not quite as bad as the disease.... It is not likely that such an alteration will ever occur in female dress as to cause ornament to give place to utility. Nor, as we think, is a result of this kind at all desirable"

“The Fashions” The New York Times, 8 October, 1875.

Such was the legacy of the efforts of Amelia Bloomer, Elizabeth Cady Stanton, and Elizabeth Smith Miller to launch a public attack on mainstream American fashion, and the gender inequality it had come to represent. While their attempt to adopt an alternative garment, the "Bloomer Costume," in 1851 was meant to symbolize equality between men and women, instead it exposed both women and the feminist cause to mockery, criticism, and disgust from both the media and the public. Faced with such disempowering national attention, many women, including the highly visible figures of first wave feminism, Bloomer and Stanton, gave up the Bloomer costume in favour of traditional dress. This very public symbol of defeat led both their contemporaries and modern scholars to view the nineteenth-century dress reform movement as a failure. Yet beneath the highly publicized "Bloomer Movement" lay a complex web of individuals, communities, and organizations who sought to challenge and reform female dress. It is these subcultures that are essential to a complete understanding of dress reform. By looking beyond the highly publicized "Bloomer Costume," which endorsed pants as the means to emancipation, I will explore the intricate ways in which dress reformers challenged gender binaries and actively reclaimed the Victorian woman's body by pushing beyond the traditional model of male clothing as indicative of power. 
At the very time the New York Times reporter declared the dress reform obsolete, a subculture, Aestheticism, thrived below the surface of American culture. Scarcely noticed by the critics of dress reform, the aesthetes subversively challenged the notions of dress and gender. While the women who donned the "aesthetic dress" initially appear to have little in common with Bloomer and her colleagues, I will argue that they constituted a legitimate component of nineteenth-century dress reform. Emerging from the European artist's studio and appearing publicly and domestically in long dresses, the North American women who appropriated this fashion did not formulate a cohesive attack against the inequality of women and men in Victorian America. However, their exploitation of female representation in ancient art allowed them to advocate healthful dress in a socially acceptable manner, while at the same time transforming their wardrobe into a public art form. In doing so, not only did they defy the moral implications of domesticity, but they also assumed greater cultural agency in their society at large. Unlike the "Bloomer Movement", the aesthetic dress slipped into mainstream fashion, soon emerging in Paris fashion houses, in the closets of the upperclass female, and finally in the wardrobe of the everyday American woman. ${ }^{1}$ Thus, while in the eyes of the New York Times reporter, and subsequent historians of dress reform, the movement had become obsolete following the public failure of the Bloomer costume, my examination of the aesthetic counterculture will demonstrate how American women continued to pursue emancipation through and from fashion long after the public disgrace of the self-identified feminist dress reform movement.

\footnotetext{
${ }^{1}$ While I found substantial evidence to indicate that the aesthetic dress reform transcended class boundaries there is not enough evidence to indicate conclusively that aesthetic dress also transcended racial categories. 


\section{The Separate Sphere Doctrine and the "True Woman"}

Before examining the scholarship on the dress reform movement, it is useful to understand the dominant constructions of gender ideology present in nineteenth century America. Barbara Welter examines Victorian women's magazines, gift annuals, and religious literature to expose "The cult of true womanhood", a set of ideologies which enforced the status of ideal woman as a "hostage of the home". 2 Welter exposes the widespread belief that this woman, exclusively a white, upper-class female, ought to adhere to four cardinal virtues -piety, purity, submissiveness, and domesticity-making her an ideal mother, daughter, sister and wife. ${ }^{3}$ Welter's examination of this idealized gender separation forming the basis for Victorian America makes it clear that even a choice in wardrobe, a seemingly minor decision, was part of a complex and deeply entrenched social framework, built upon a "separate spheres doctrine".

\section{Mainstream Fashion in Victorian America}

When writing on the "Bloomer Costume" in 1963 historian Robert Riegel posed this question: "Why was it necessary to create a movement to press for changes in personal attire that were under the control of any woman?"4 Riegel's inquiry draws us into the complex ideologies of gender and femininity which formed the very basis of

\footnotetext{
2 Barbara Welter, "The Cult of True Womanhood: 1820-1869", American Quarterly Vol. 18 (1966): 151.

${ }^{3}$ Ibid., 152

${ }^{4}$ Robert Riegel. "Women's Clothes and Women's Rights." American Quarterly, 15, no 3 (1963): 603
}

Past Imperfect

13 (2007) | ( ) | ISSN 1192-1315 
Victorian fashion, and exposes a society in which choice in attire was not personal, but highly political. Writing seventy-five years prior to Riegel, feminist and author Charlotte Perkins Gilman provides us with the foundation of an answer to this question. She observed, "Cloth is a social tissue. By means of its convenient sheathing we move among one another. The more solitarily we live, the less we think of clothing; the more we crowd and mingle in 'society' the more we think of it". 5 The launch of Goody's Lady's Book in 1828, and Harper's New Magazine in 1850 signified the development of a forum in which notions of fashion and femininity were regularly distributed to upper and middle class women across America. A look at a typical issue of Goody's Lady's Book illustrates how important fashion had become. Each issue is rich with fashion plates, recreating designs flooding out of fashion houses in France, and each was accompanied with a detailed analysis of dresses, shoes, hats, and so on. ${ }^{6}$

Popular fashion had clearly become much more than a utilitarian form of protection against the elements. As contemporary scholar Mary M. Blanchard points out, the template of the Victorian body followed a gendered separation. The Gilded Age upper and middle class male body was presented as virile, patrician and public, dressed in comfortable pants and frock coats, and was complemented by the female form, highly ornamented, and bound by tight corseting, connotating domestic confinement and frivolity, thus visually reinforcing the notion of "true womanhood". 7 Not only did

\footnotetext{
${ }^{5}$ Charlotte Perkins Gilman, The Dress of Women: A Critical Introduction to the Symbolism and Sociology of Clothing (Westport: Greenfield Press, 2002) 29

${ }^{6}$ Blum, Stella. ed. Fashions and Costumes from Goody's Lady's Book (New York: Dover Publications, 1985): 22

${ }^{7}$ Mary W. Blanchard, "Boundaries and the Victorian Body: Aesthetic Fashion in Gilded Age America.” American Historical Review, (1995): 21.

Past Imperfect

13 (2007) | @ | ISSN 1192-1315
} 
popular fashion create a rigid division between masculinity and femininity, but for women, fashion ensnared them in a dangerous double standard. ${ }^{8}$ To adhere obediently to the popular style was frequently referred to in the mainstream press as a confirmation of women's inferiority in terms of rationality, courage, and intelligence. Styles were fleeting, changing with each season, and one man writing in 1868 argued that fashion "...reflects an irreconcilable stupidity which is being so fast developed in the characters of our women". 9 Popular songs of the 1840 s, such as "I Really Must be in Fashion" poked fun at the female fetish for stylish clothing. However, as scholars Jeanette C. Lauer and Robert H. Laurer argue, though men complained about female subservience to fashion, they reserved for themselves the right to preside over any changes in fashion. ${ }^{10}$ Assuming personal agency over wardrobe was clearly much more than a matter of individual choice. Since articles of clothing had been designated as masculine or feminine, to disregard these distinctions was to disregard the relationship between the sexes as it was ordained by God. Moreover, in an era where femininity was a commodity on the marriage market, to challenge the gender norms dictated by fashion was a risk few Victorian women could afford to take.

\section{The "Bloomer" Movement: Inception and Backlash}

It is useful to examine the rise and fall of the Bloomer movement in order to understand the politicization of the costume, assess the reasons for the unpopularity of this reform dress, and address the

\footnotetext{
${ }^{8}$ Jeanette C. Laurer and Robert H. Laurer, "The Battle of the Sexes: Fashion in $19^{\text {th }}$ Century America" Journal of Popular Culture, 13, no. 4, (1980): 585.

${ }^{9}$ New York Times, 25 Feb. 1868.

${ }^{10}$ Laurer and Laurer, "The Battle of the Sexes," 588

Past Imperfect 13 (2007) | @ | ISSN 1192-1315
} 
ways in which this challenge to popular fashion set a precedent for future reform, in particular "aesthetic dress". Mid-century dress reformers were aware of the intricate network of cultural norms which inhibited women from challenging dominant fashion. These early groups fixed their reforms around the symbol of the pants, connecting the liberation from the long dress with the assertion of female power both in and beyond the sphere of fashion.

Evidence of dissatisfaction with female dress became increasingly prevalent in 1840 s America. Alternative communities such as the residents of Oneida County chose to distance themselves from society, creating spaces in which women were encouraged to wear pants away from the critical eyes of the Victorian public. However it was the actions of Amelia Bloomer, publisher of the feminist newspaper The Lily, and a close friend of the highly publicized activist for women's emancipation, Elizabeth Cady Stanton, which politicized the female wardrobe. Stanton and Bloomer's involvement in this branch of dress reform served to inextricably link the agenda to goals of female equality Stanton proposed at the 1848 Seneca Falls Conference. Arguing that "The history of mankind is a history of repeated injuries and usurpations on the part of man toward woman, having in direct object the establishment of an absolute tyranny over her" ${ }^{\text {"11 }}$ Stanton suggests the only option for the Victorian woman is to, "to throw off such government, and to provide new guards for their future security". ${ }^{12}$ Stanton's address not only signals the inauguration of First Wave feminism, but also the imminent backlash against these goals of equality between genders. Writing on the activities of Cady Stanton

\footnotetext{
${ }^{11}$ Stanton, Elizabeth Cady. "Declaration of Sentiments", Seneca Falls Conference, 1848. from A History of Woman Suffrage, vol 1. (Rochester, NY: Fowler and Wells, 1889) 70.

${ }^{12}$ Ibid., 71. 
and her colleagues in 1852 a New York Times reporter remarked, "We very much question the use or propriety of calling Conventions of the sex, as a class for their consideration or vindication... She was given to man as a companion. For such Nature has eminently fitted her". ${ }^{13}$ In 1851, amidst this volatile reaction to the Declaration of Sentiments, Bloomer first donned what came to be known "Bloomer Costume," an outfit consisting of pantaloons worn beneath a shortened skirt (Appendix 1). The notion of reform dress soon became synonymous with the controversial demands for the equality proposed at the Seneca Falls Conference. For Bloomer and her colleagues "pants" were inextricable from the concept of power. As these dress reformers argued, only through the comfort and mobility afforded by pants could they hope to play an active role in the public sphere, assuming positions of dominance typically reserved for men. As Bloomer noted in her feminist newspaper, The Lily, "How painful to the female to strive to walk, her dress flapping in the breeze, assuming all the gyrations of a ship in a storm."14 Highly public leader of the feminist movement Elizabeth Cady Stanton expanded on the political disadvantage of popular fashion, criticizing the way in which the long skirt prevented women from walking, running, or climbing with the ease and comfort of their male counterparts. ${ }^{15}$ She argued,

How can we ever compete with a man for equal place and pay, with garments of such frail fabrics and so cumbersomely fashioned, and how can we ever hope to enjoy the same heath and vigor with a man, so long as pounds of clothing is hung on the hips, the limbs

\footnotetext{
13 "Women's Rights_-Proposed Convention.” New York Daily Times, Aug 31, 1852

${ }^{14}$ Amelia Bloomer, "Female Attire", The Lily, 3 (March, 1851): 21

${ }^{15}$ Elizabeth Cady Stanton, "The New Dress", The Lily, 4 (April 1852): 27 
cramped with skirts, with high heels, and the whole woman out of her true equilibrium. ${ }^{16}$

Stanton concluded that the long skirt left women to assume a public pose a "fettered criminal", rather than walking with a "dignified, majestic step, as joyous as some poor captive who has just cast off his ball and chain."17 Bloomer's costume was meant to provide women with the opportunity to participate in active, public life, as men were able to do, free of cumbersome clothing, and as such can be seen as a demand for equal status with men.

Bloomer and Stanton's advocacy of the Bloomer costume caught national attention with greater speed than any prior attempt at dress reform in Victorian America. They, and other visible feminists, such as Susan B. Anthony and Elizabeth Smith Miller, appeared publicly in the Bloomer costume, actively defying the norms of Victorian fashion, and the ideologies of gender it represented. Stanton declared in 1853, "I am willing to encounter a lifetime of ridicule and rebuke, if the blessing of free powers of locomotion can be gained thereby."18 Yet a few years later, Stanton, Bloomer, and their colleagues gradually gave up the Bloomer costume and returned to traditional dress. What precipitated this reversal of attitudes in these and many other women? For many, the backlash against their wardrobe was not only psychologically draining, but as feminists such as Stanton and Anthony felt, the dress was drawing attention away from what they thought were matters of greater importance, namely the question of women's rights to better education, a wider field of employment, and to the ballot. ${ }^{19}$

\footnotetext{
${ }^{16}$ Ibid.

${ }^{17}$ Ibid.

${ }^{18}$ Stanton, "The New Dress," 26.

${ }^{19}$ Jennifer Ladd Nelson. "Dress Reform and the Bloomer". Journal of American and Comparative Culture. 23 (2000): 24

Past Imperfect

13 (2007) | @ | ISSN 1192-1315
} 
The public reaction to the Bloomer costume was intense, inciting criticism from both men and women, indicating that the reform dress provoked ridicule rather than the empowerment for women that had been sought. The media was often the harshest critic of the costume, setting the standard for popular opinion. An editorial from the New York Times of 1851 read, "The propriety of endowing their delicate forms with the apparel, appurtenances, and insignia of 'manhood' cannot be too severely rebuked or too speedily repressed. $" 20$ An editor of a later issue proclaimed it time for physicians to "...carefully investigate the nervous disorder peculiar to women which is vulgarly called "dress reform" and which is characterized by an abnormal and unconquerable thirst for trousers...Further investigation will probably show that the disease is simply hysteria." ${ }^{21}$ Such articles demonstrated contempt for the way in which the "masculine" Bloomer costume sought to impose women on the male world.

While the dress reformers were exposed to open hostility from the media, they were also met with mockery and humiliation in the form of satiric songs, such as the "The Bloomer's Complaint: A Very Pathetic Song",2 of 1851 and the proliferation of cartoons parodying the Bloomer Costume in Punch Magazine and Harper's New Monthly Magazine. Both the harsh attacks by journalists, and the satire made of Bloomer and her followers reflected the extent to which a seemingly individual choice of personal attire was seen as an attack on the gender norms of Victorian America. Punch cartoons portrayed the Bloomer women as "masculinized" smoking, courting, and dominating their male counterparts, while men in the images are

20 “Women's Rights", The New York Times, 18 October , 1851.

21 “A Curious Disease” The New York Times, 27 May 27' 1876.

22 "The Bloomer's Complaint: A Very Pathetic Song", Historic American Sheet Music, http://memory.loc.gov/ammem/index.html, (15 July, 2007).

Past Imperfect

13 (2007) | @ | ISSN 1192-1315 
pictured in poses of submission, often made to seem effeminate (Appendix 2). ${ }^{23}$ The Bloomer costume became the centre of public ridicule, and even those who had expressed moderate support for female dress reform became increasingly alienated from the movement. One elderly doctor who believed that good sense and convenience should be considered in female dress, did not like "...the exaggerated and ridiculous caricatures exhibited on the stage and in our shop windows", and thus gave up his support for the Bloomer costume. ${ }^{24}$ While liberation from long and heavy skirts provided Bloomer, Stanton and their followers with greater freedom of movement, the Bloomer costume brought anything but empowerment and equality. Stanton recalled her experiment at reform dress as characterized by criticism, ridicule, and persecution. Just as adherence to popular fashion had called into question female rationality, many men argued no woman of any intelligence would appear publicly in the much-scorned Bloomer costume. Feeling they had little alternative, Stanton, Anthony, Bloomer and many other feminists humbly returned to the long dresses they had fought to free themselves from.

It is here that most scholarship on the nineteenth century Dress Reform Movement ends. With most of the highly public figures abandoning their assault on fashion by 1860 , historians have been inclined to downplay the Bloomer costume and dress reform as simply a "fad" of the feminist movement. ${ }^{25}$ However, more recent scholarship has sought to acknowledge the multiplicity of dress reform communities, and it is this line of inquiry I will follow to extend my examination of dress reform beyond the Bloomer

${ }^{23}$ Punch's almanack. (London: Punch Publications Ltd., 1851).

${ }^{24}$ The Ladies Repository, (13 Jan, 1853), 8 http://quod.lib.umich.edu (16 July 2007).

${ }^{25}$ Amy Kessleman, "The 'Freedom Suit': Feminism and Dress Reform in the United States: 1848-1875. Gender and Society, December (1991):13, 495. 
movement. Amy Kesselman considers the Bloomer costume's roots in the health reform movement, looking specifically at the alternative lifestyles of women involved with "Water curists", a group that sought to reform society through healthful living. Gayle V. Fischer looks beyond Bloomer and her colleagues, to trace the notion of "pantaloons and power" into present-day American culture. ${ }^{26}$ However, despite this recognition of a broader sphere of dress reform in American culture, much of the historiography indicates a tendency to view only complete abandonment of the long dress in favour of pants as a legitimate dress reform movement. In fact, as I will indicate, as the century progressed, the corseted female waist, rather than the skirt, became an equally, if not more salient, example of female disempowerment in popular fashion.

\section{The Medicalization of the Victorian Woman's Body and the Problem of the Corset}

In January of 1875 Peterson's Magazine heralded the fashion of the New Year, the bustle. ${ }^{27}$ In this new extreme of high fashion, the female form became scarcely recognizable beneath layers of fabric, tightly corseted at the waist, with fabric and hoops. As historian Leigh Summers notes, throughout the latter half of the decade the female waist was the cause of more controversy than any other part of the female body. ${ }^{28}$ The corset represented a very tangible symbol of the "true woman's" submission and domesticity through the regulation of her "coarse bulges". The waist as a deeply ingrained component of female identity cannot be underestimated, and is

${ }^{26} \mathrm{Ibid}$.

27 "Peterson's Magazine, www.copyrightexpired.com/fashions/petersons.html: 1875

Vol. 22 No.1, (15 March, 2006).

${ }^{28}$ Leigh Summers, Bound to Please. (New York: Berg, 2001), 97.

Past Imperfect

13 (2007) | @ | ISSN 1192-1315 
further indicated by the reluctance of even Bloomer and her colleagues to give up their corsets. ${ }^{29}$ However, the contrast between the glamorous corseted women of the fashion plates and the adverse affects of corsetry on women's health, indicates that a dangerous gap existed between popular fashion and the physical well-being of Victorian women. The awareness of medical professionals of the costs of corsetry to the female body, combined with their reluctance to speak on behalf of these women highlights the need for a dress reform movement that would effectively challenge the styles of tight lacing.

In her examination of the troubling relationship between Victorian woman and their doctors, Ann D. Wood proposes the notion that medicine was based on veiled but aggressively hostile male sexuality and superiority. As she claims, "Acting in fear doctors manipulated women both physically and psychologically; physicians and their patients were engaged in subtle, but vicious psychological warfare." ${ }^{30}$ Wood's argument seems particularly valid when considered in relation to women and the corset. For many nineteenth century doctors the corset was not only a socially acceptable component of the woman's wardrobe, but was also a normal and healthful regulation of the female body. Writing in 1881 one doctor argued that "Nature demands that women should have small waists, and the misery and harm...inflicted by the overuse of corsets is only a blind obedience to instinct, which properly directed is natural." 31 Dr William Goodell, in his often reprinted medical manual, Lessons in Gynecology, like many of his colleagues

\footnotetext{
${ }^{29}$ Ibid., 98.

${ }^{30}$ Ann D. Wood. “The Fashionable Diseases': Women's Complaints and Their Treatment in Nineteenth-Century America" Journal of Interdisciplinary History 4 (Summer 1979): 28.

${ }^{31}$ Ibid., 93 
attributed any corset related health problems to forays into the public sphere. He insisted that too much "brainwork", and too little housework spelled disaster for the female body. Likewise, the Manual of Gynecology published in 1888, stated that female education led to a rapid development of the brain and nervous system accompanied by feebleness of the muscular system and feebleness in the generative organs. ${ }^{32}$ Yet Rachel B. Gleason, one of only four women to hold an M.D. in America in 1847, contended that the nonchalant dismissal by medical professionals of female health problems was cause for great concern, and was convinced that the corset was the source of many women's complaints. She recalled,

Our professor of Anatomy said to the class when demonstrating the location of the liver, 'Its lower border corresponds to the lower margin of the ribs usually; but in women it is sometimes extended to the internal cavity of the hip bone. If you wish to find all the organs in their normal position, procure a male subject. ${ }^{33}$

One of the most adverse, yet rarely discussed effects of the corset was uterine displacement and prolapse. The tight-lacing created a condition in which the uterus was forced through the cervix, protruded into the vagina, and in extreme cases outside the body. ${ }^{34}$ The delicate nature of this health concern led many women to keep their suffering to themselves. Most women were too ashamed to discuss such an intimate issue with their female acquaintances, let alone approach a male medical professional with the problem. Harriet Beecher, who suffered from the condition, expressed the

${ }^{32}$ Manual of Gynecology, 1881, as cited in, Helene E. Roberts. "The Exquisite Slave: The Role of Clothes in the Making of the Victorian Woman" Signs, (1977): 561

${ }^{33}$ Rachel Brooks Gleason. "Woman's Dress”, Water-Cure Journal, 11 February 1851,31

${ }^{34}$ Summers, Bound to Please, 102

Past Imperfect 13 (2007) | @ | ISSN 1192-1315 
isolation and fear experienced by women suffering from uterine prolapse, writing, "Many a woman is moving about in uncomplaining agony, who with any other trouble involving equal suffering would be on her bed surrounded by sympathizing friends." It is apparent that this was not a condition that befell a minority. In one year alone, Rachel Gleeson treated 130 cases of uterine 122| prolapse. $^{35}$

\section{Beyond the Bloomer Costume}

What were women to do? As The New York Times indicated in 1875 there was little public sympathy for the "absurd" ideas of the dress reformers. Instead, as the paper brashly stated, “...scarcely anything needs to be reformed at all. ${ }^{, 36}$ Based on the medical evidence, this was clearly not the case. Now more than ever, women were in need of an alternative form of dress that would allow them to reclaim their own health. Yet the Bloomer costume had proved not to be a viable option. As accurately noted by dress reformer Abba Gould-Woolson in 1874, the advocates of the Bloomer costume had "...overrated the intelligence and courage of their followers, and they had underrated the strength of their opponents. To reintroduce the Bloomer costume would invite another defeat and dishearten dress reformers in the future" ${ }^{\text {37 }}$. Could American women find a middle ground between public ostracism and personal subjugation?

Ironically the very same New York Times article that proclaimed the "death" of dress reform, points the way towards this middle ground. The author argues that, "One of the things that is

\footnotetext{
${ }^{35}$ Gleeson, "Woman's Dress," 31.

36 "The Fashions," The New York Times, 8 October 1875.

${ }^{37}$ Summers, Bound to Please, 153

Past Imperfect

13 (2007) | @ | ISSN 1192-1315
} 
most needed for a real and genuine dress reform is that women should appreciate her own loveliness. ${ }^{38}$ While this statement simplifies the battle fought over the female right to the selfdetermination of "loveliness", it nevertheless highlights a shortcoming of the Bloomer costume. As Elizabeth Smith Miller, who had been actively involved in both the feminist movement and the Bloomer reform movement recalled, "The [bloomer] dress looked tolerably well standing and walking, but in sitting it produced an awkward uncouth effect. It was a perpetual violation of my love of the beautiful. So, by degrees, as my aesthetic sense gained ascendancy. I lost sight of the great advantages of my dress...,

While Smith viewed herself as a "victim of beauty" and recounts her return to skirts as characterized by the desire to avoid public humiliation, looking closely at her statement I believe a second interpretation is necessary. The Bloomer costume required women to view their femininity as a weakness. By discarding the skirt, symbolic of womanhood, to assume pants, symbolic of male power, the Bloomer costume required a certain sacrifice of the female sense of self, and on a deeper level suggested femininity and empowerment could not coexist.

\section{From European Art Studios to the American Household:} Aesthetic Dress and American Fashion

The discovery of the ancient Greek statue of the Venus de Milo in 1820 sparked a renaissance in ancient ideals of female beauty in Europe, a trend which was quickly transmitted to North America,

\footnotetext{
38 "The Fashions," New York Times, 8 October 1875.

${ }^{39}$ Elizabeth Gerrit Smith, "Reflections on Women's Dress, and the Record of a Personal Experience", Arena (September 1892): 495.
} 
and was at the heart of a dress reform movement that emerged to provide a venue in which femininity and empowerment could act in harmony. The term "aesthetic dress" was first used by the English Pre-Raphaelite painters of the 1840 s and the 1850 s to describe the clothing worn by their models and their female acquaintances. Disgusted with the way in which Victorian corsets, bustles and petticoats distorted the natural lines of the female body, painters such as Dante Gabriel Rossetti and John Everett Millais looked back towards the figure of the Venus de Milo as a more accurate reflection of the female body. They chose to paint their female subjects in loose-fitting dresses of Greek origin to allow the natural lines of their subject's bodies to be appreciated (Appendix 3). By 1874 a template for the aesthetic dress was firmly in place, and poised to circulate in mainstream American society. With the introduction of the concept of an artistic dress through the guise of high art, the garment gained social acceptability where the Bloomer costume had not. This rupture in the social fabric gave American women the opportunity to reclaim their bodies and promote "aesthetic dress" for their own purposes.

Historian Robert Riegel argues that all proposals for alternative dress at the close of the nineteenth century tended to be anti-climatic, showing little imagination. He refers to artistic dress as an extreme, taken seriously by few. ${ }^{40}$ Yet Mary W. Blanchard counters that "aesthetic dress" was in fact a very significant alternative form of dress, and permeated every class in America. ${ }^{41}$ My examination of the aesthetic dress movement leads me to believe that unlike the politicized costume of "feminist" dress reformers, the subtle use of artistic dress reformed fashion more lastingly (albeit

\footnotetext{
${ }^{40}$ Riegel, "Women's Clothes and Women's Rights," 397.

${ }^{41}$ Blanchard, "Boundaries and the Victorian Body," 22

Past Imperfect

13 (2007) | @ | ISSN 1192-1315
} 
subtly) than Bloomer and her colleagues could have ever imagined. By first analyzing the artistic reformers attack on corsetry, and second, by evaluating their use of their reform garments to assume greater agency in society, I will demonstrate the way in which "artistic dress" allowed many women to reassume control over their bodies and their identity. While Aestheticism originated in Europe, the ideals which shaped the movement proved particularly palatable for American women, offering a "rational dress" that could fill the void in wardrobe reform left by Bloomer and her colleagues. That this movement to emancipate women from the shackles of popular fashion was incorporated into mainstream American society and offered women a socially acceptable alternative to corsetry indicates the "artistic dress" was a valid and highly influential component of nineteenth-century dress reform. ${ }^{42}$

The path that the Aesthetic dress movement took in America was greatly influenced by the British aesthetic movement. An outpouring of literature from British female authors championing the virtues of aesthetic dress gradually increased the visibility of aesthetic dress in the late 1870s. Titles such as The Art of Dress, The Aesthetics of Dress and Dress as Fine Art all authored by women, addressed the concern that the corset violated the very nature of the female form, an ideology which was quickly grasped upon by American women. The problematic nature of corsetry was the focal point of many American aesthetes' enthusiasm for artistic dress. American writer Charlotte Perkins Gilman challenged the beauty of corseted female figure, writing, "If the great statue from Melos is beautiful, why do we not seek to approximate her proportions. How

${ }^{42}$ For a discussion of a dress reform movement that followed a similar trajectory, see Carin Schniter "Woman's Dress Reform in the Netherlands". Textile History 24:1, (1993): 23-36. 
can we admire this statue and at the same time admire women around us?"43 Dr. Rachel Gleeson's experience with her female patient's corset-induced ailments led her to become an early advocate of a return to sensible dress, arguing,

True, thousands of long and slender waists have been made which are called beautiful. But were our standard of beauty the one given to us by Infinite Wisdom, we should cease to admire such. How much more beautiful the loose flowing robes of the ancients, allowing the freedom of motion to every joint and muscle. ${ }^{44}$

Writing in 1880 Mary Haweis encouraged a style of dress that followed the natural lines of the female body, while Mrs. Oliphant included a chapter on "Ancient Costume" in her study of dress as artistic expression. ${ }^{45}$ Mrs. Charles Bernard delivered a lecture to aspiring actresses in New York in 1873 which encouraged them to assume a stage costume of simple natural lines. ${ }^{46}$ Annie Jenness Miller emerged as a vocal leader in the Artistic Dress movement, and both her public lectures and her periodical, Dress advocated individual female agency over personal attire. In 1888 Miller encouraged women to liberate themselves from conformity to French fashions. She appealed to women that they could remain "very visions of loveliness" while freed from the "evils of the corset". ${ }^{47}$ In an article on maternity dress, Miller also expressed concern for the way many pregnant women insisted on wearing the corset, despite the threat it posed to mother and child. Though implicitly political,

\footnotetext{
${ }^{43}$ Gilman, The Dress of Women, 47.

${ }^{44}$ Ibid., 11.

${ }^{45}$ Oliphant, Dress. Philadelphia: Porter and Coates, (1879) http://hearth.library.cornell.edu/, , 99, (26 March, 2006).

46 "Lecture to Actresses on Dress" New York Times, Oct 19 ${ }^{\text {th }}, 1873$.

${ }^{47}$ Annie Jenness Miller, "Dress Reform”, from Dress, 1888. 
Miller's lectures, rather than putting forth a blatant political challenge to the dominant gender norms, sought to instead reaffirm value to the natural female form. Through the artistic dress she sought to advocate a more healthful image of female beauty.

While the opportunity for liberation from the corset was at the forefront of many artistic dress advocates' arguments for the garment, the dress also became a tool with which women could subvert the notions of the domestic female. Though as a modern audience we might be inclined to criticize the women of the movement for their willingness to regulate themselves to the persona of the feminine artist's "model", in fact their manipulation of this identity became a challenge to male dominance of the public sphere. Women used their bodies and their dress as public art forms, not only to defy the moral implications of domesticity, but to assume cultural agency in society at large. By creating herself as both a performing public self and individual work of art, the aesthetic women challenged the traditional concept of the female artistic object with the new concept of female as artistic subject. ${ }^{48}$ In this light the aesthetic dress can be seen to be a form of individual female expression. As female aesthete Catherine Tinker wrote, "To dress well is to make a picture of oneself. To express beauty in every line of the dress, in the selection in every colour, in every detail is as if the very soul of the individual was revealed." ${ }^{49}$

While such an appreciation of beauty was what feminist dress reformer Elizabeth Gerrit Smith had viewed as her weakness, to the women of the artistic dress movement, appreciation of their own individual sense of beauty was the strength which allowed them to reassume control over their bodies. Moreover, the increasing

${ }^{48}$ Blanchard, "Boundaries and the Victorian Body," 22.

${ }^{49}$ Ibid., 23.

Past Imperfect 
regularity with which women appeared in public in the artistic dress represented a gradual loosening of the boundaries between the private and public spheres. The artistic dress, very similar in appearance to the wrapper, an article of clothing traditionally meant to be worn only within the home, was brought by the aesthete into the public eye, recasting the female body from shamefully hidden within the home, to be celebrated in the public realm. Here, to a certain extent, we see the Victorian woman emancipated from the hostage status in of the "true woman", as the female aesthete moved beyond the domestic sphere. Moreover, rather than conforming to what some fashion plates dictated as feminine, the aesthetes often created their own costumes based on personal inspiration, to reveal individuality and personal agency over their physical and psychological identity.

In 1893 a French fashion designer spoke to a New York Times reporter, proclaiming, "I have struggled all my life to modify forms and dress outline; to render those not only graceful and beautiful, but healthful and practical, not permitting anything in any toilet to break the beauty, line or grace of the wearer." ${ }^{\text {50 }}$ By the turn of the century the once countercultural status of the artistic dress had been commodified and legitimized in the mainstream fashion industry. While never adopted universally by the women of America, the creation of an alternative to the health violations of traditional Victorian dress suggests that the overlooked "artistic dress" did represent a valid dress reform movement, providing individual women with greater agency in choosing clothing, which in turn, allowed for greater comfort and freedom without fear of ostracism.

50 “Two Foes of Crinoline". The New York Times, 20 March, 1893.

Past Imperfect

13 (2007) | @ | ISSN 1192-1315 
In evaluating the success of the "aesthetic dress," it is useful to examine the various ways it infiltrated American life, and contrast its mainly positive reception to the backlash against the Bloomer costume as discussed previously. Whereas the Bloomer costume had made a loud and defiant attack against mainstream American sensibilities, the aesthetic dress not only emerged from the respected circles of high art, but moreover was transmitted from the highly esteemed European culture which upper-class Victorian Americans often sought to emulate. While the Bloomer costume almost instantaneously sparked ridicule, satire and hostility in the press, open hostility in either of these mediums to the "artistic dress" was minimal. In contrast, the majority of public opinion on aesthetic dress appeared to lean towards curiosity, enthusiasm, and support for the values the aesthetes promoted. In 1881 The New York Times ran a feature on "Art in Dress" which welcomed "...the attempts in London to revive Greek drapery for women”, arguing that such a style of dress “...can do anything but affect us pleasingly first and last." ${ }^{, 51}$ While the dress itself won the praise of the press, so to did the American women behind the movement. Annie Jenness Miller, possibly the most outspoken advocate of artistic dress was referred to as the subject of much love by those present at her lectures, and discussed favorably as an advocate of sensible dress for women. ${ }^{52}$ Even Harper's New Magazine, traditionally the advocate of the restrictive Victorian wardrobes pouring out of French fashion houses, featured an article which echoed the words to the aesthetic dress reformers, proclaiming,

51 “Art in Dress", The New York Times, April 24 $4^{\text {th }}, 1881$.

${ }^{52}$ Ibid.

Past Imperfect 
Tight lacing is not only a stupidity, it is a crime, a crime that casts a heavy burden upon the next generation...We would like to convince every woman in the land that a small waist is un-beautiful. Look at the Greek statues. We have no more perfect standard for beauty. ${ }^{53}$

Beyond the media, male public figures also picked up on the messages of the artistic dress reformers. On his 1882 tour of America Oscar Wilde found a receptive audience for his lectures on the inhumane nature of female fashion, his observation, “... it is really sad to think that in our own day a woman was hang on to a cross bar, while her maid laces her into a 15 inch circle"54 clearly indicating that the concerns of American dress reformers of interest to a mainstream audience. Finally it seems, there was a consensus between medically sound clothing for women, and the respect garnered for women who donned such "rational" dress.

While it is clear the artistic dress made a mainly positive impact on mainstream culture, the extent to which American women adopted the garment in their daily life requires more examination. Initially, women featured in the Aesthetic Dress were members of high-art circles, who would have come into contact with the artists who first developed the costume. Yet as early as 1875 there was a proliferation of the artistic style, conforming to the basic principles of the dress: loose-fitting, and light weight. Photographs from 1890s of the upper classes present wealthy women attending social functions in the loose-fitting "tea gown". While initially this form of aesthetic dress was restricted to married women, and was expected only to be worn for afternoon tea within the home, before the century

\footnotetext{
53 “On Tight Lacing and Red Noses" Harper's Bazaar, Nov 2. 1867 at: http://harpersbazaar.victorian-ebooks.com (16 March, 2006).

${ }^{54}$ Oscar Wilde, "More Radical ideas Upon Dress Reform" Pall Mall Gazette 40, ( 6224), 11 November 1884.
} 
was over these rules changed. Gradually tea gowns were worn in the company of others and soon the lines of the tea gowns were copied for outdoor dresses. ${ }^{55}$ By 1890 the tea gown appeared in upscale American department stores, such as Marshall Field's and Macy's, was present in periodicals of the era (Appendix 4) and became widely available in mail-order catalogues. A Canadian women's magazine reported that the tea gown was a stylish alternative to corsetry, and advertised aesthetic dresses such as the "Athene" and the Japanese kimono designed by the British store Liberty and Co. ${ }^{56}$ In the daily life of American women, the aesthetic dress came to symbolize a progressive sensibility. The diary of a young American woman, spanning the years 1889 to 1900 , indicates the way in which loose-fitting garments began to connote modernity, and the diarist discusses her decision to don artistic dress as indicatative of her ability to keep with the times. ${ }^{57}$

While for the most part the dress reform movement was restricted to the sphere of the white, upper-class women, near the close of the century there is a marked increase in the availability of images of middle- and working-class women in the public sphere in a version of artistic dress. Blanchard argues that American women of all classes began to incorporate some form of artistic dress into their wardrobe. ${ }^{58}$ Indeed, rather than being solely confined to elite circles of artists, artistic dress appeared to have had a middle-class following. An 1878 issue of the American Agriculturist published

\footnotetext{
${ }^{55}$ Patrica E. Bovey, Bustles and Rose petals: Fashion is Art, 1882-1910. (Winnipeg: The Winnipeg Art Gallery, 1980), 15.

${ }^{56}$ Eileeen Collard, The Rise and Fall of the Bustle. (Burlington: Eileen Collard, 1979).

${ }^{57}$ Rebecca J. Kelly "Fashion in the Gilded Age: A profile of Newport's King Family" in Twentieth Century American Fashion, Patricia Cunningham ed. (New York: Berg: 2005), 27

${ }^{58}$ Blanchard, "Boundaries and the Victorian Body," 21. 
with a rural readership in mind observed with approval that the aim of the Pre-Raphaelite style was to "have a thick waist", like the Venus de Medici and Venus of Milo. ${ }^{59}$ Moreover, there is rich photographic documentation of women of all classes in artistic dress to substantiate the notion of the class transcendence of Aesthetic Dress. A picture of a stenographer at work in 1884 captures a young woman in a dress simply gathered at the waist, and loosely draped over the body. ${ }^{60}$ A nurse appears in a photograph from 1892 wearing a light cotton wrapper, which was likely purchased from a ready-towear catalogue of the late nineties (Appendix 5). A working-class pregnant woman is featured wearing an off-shoot of the artistic dress, the "mother Hubbard." healthful alternative to mainstream fashions during pregnancy, a change aesthetic dress reformer Jenness Miller had advocated in her public lectures. The mother Hubbard became extremely popular among women as an alternative to heavy clothing during the hot summers, and could be made easily and affordably by women at home. A simple alternative to corsetry, the evidence of the tea gown, the wrapper, and the mother Hubbard in turn of the century portraiture represents the extent to which aesthetic dress reform permeated both upper class and working class society. While the artistic dress did not immediately destroy conventional Victorian fashion norms, there is evidence that the dress, if not the ideologies behind it, filtered through all classes in American society, allowing women greater comfort in their daily lives.

My argument for the inclusion of the "aesthetic dress" as a key component in the history of dress reform in America is by no

59 "Aesthetic Dress", American Agriculturalist, 1878.

${ }^{60}$ Joan L. Severa. Dressed for the Photographer: Ordinary Americans and Fashion, 1840-1900. (Ohio: Kent State University Press, 1995), 405.

${ }^{61}$ Ibid, 531 
means an attempt to suggest that this group constituted the only true and successful instance of a movement to challenge mainstream fashion. Such were the goals of a multitude of diverse groups both in nineteenth century culture, and in the contemporary world. Rather, I have sought to indicate the way in which dress reform in America was multi-faceted and diverse. By looking beyond the most visible record and historical water mark of dress reform, the "Bloomer movement" and its advocates demand for political equality with men by donning pants, I have indicated that assuming clothing symbolic of masculinity is not the only means to empowerment in fashion. As the ideologies of the women of the "aesthetic dress" movement indicate, the celebration of femininity rather than the assumption of masculinity proved more empowering, both in a physical and social context. In a society where gender distinctions and complex ideologies of masculinity and femininity remain intact, by reevaluating our notions of equality and power between the genders though the case study of dress reform, we can seek to broaden our definition of female empowerment as not only the affirmation equality with men, but also the recognition and celebration of the feminine self. 